\title{
Ampulla of Vater Hepatoid Adenocarcinoma
}

National Cancer Institute

\section{Source}

National Cancer Institute. Ampulla of Vater Hepatoid Adenocarcinoma. NCI Thesaurus.

Code $C 95966$.

A very rare adenocarcinoma that arises from the ampulla of Vater. It is usually of the intestinal type and is characterized by the presence of malignant polygonal cells with abundant eosinophilic cytoplasm resembling hepatocytes. 